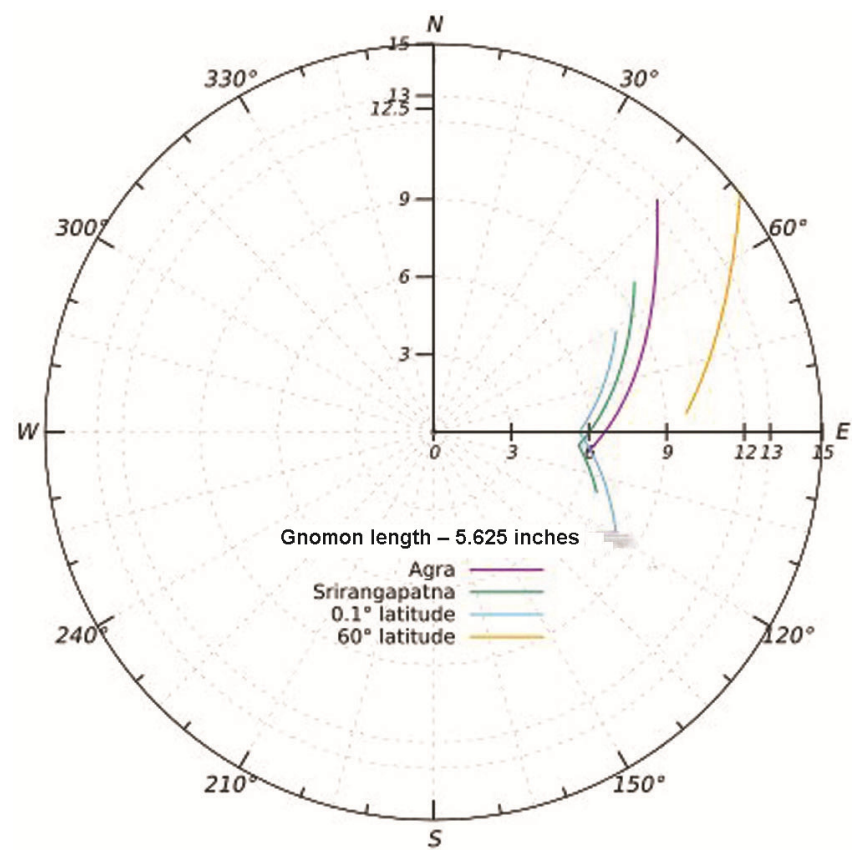

Figure 9. Comparative representation of Asr curve for different latitudes.

minima coincide on the summer solstice day. A similar coincidence happens on the winter solstice day at the Tropic of Capricorn.

Figure 9 shows a more realistic representation in polar coordinates, including additional azimuthal data for places from the equator to $60^{\circ}$ lat., exhibiting interesting shape change of the Asr curve.

The Moti Masjid sundial, though a fine piece of art, has been useless for centuries and in wrong orientation. Because of its simple, single Asr curve, the dial is also significantly different from the one at Srirangapatna ${ }^{1}$. Srirangapatna, being situated in the tropics, witnesses the Sun's zenithal passage twice a year. The size of the lower part of the Asr curve beyond the cusp signifies how close the place is to the tropical lines. Since the Sun never reaches the zenith beyond the tropics, the lower part of the Asr curve disappears.

The Asr prayer time in Agra practically extends up to sunset. It is time for the fourth prayer-Maghrib at sunset. We could successfully determine the appropriate length 5.625 inches of the missing original gnomon of the sundial in Agra by carrying out computer simulations, followed by on-site observations to resolve a longstanding puzzle.

1. Pandya, A., Tej Bahadur and Bhattacharya, S., Astronomical significance of sun-dials in Srirangapatna. Curr. Sci., 2018, 116(5), 811-816.

2. Pandya, A., Tej Bahadur and Bhattacharya, S., Sun-dial for timekeeping in Jaisalmer Fort. Indian J. Hist. Sci., 2017, 52(2), 137-146; http://insa.nic.in/UI/Journalarticle.aspx?jid=Mw==\&\&VID=MzMw$\& \& \mathrm{IsNm}=\mathrm{SXNzdWUgMg}==$

3. Sarma, S. R., A Descriptive Catalogue of Indian Astronomical Instruments, 2017, pp. 3602-3604 and references therein; http://www. srsarma.in/catalogue.php
4. Ibid; pp. 3603-3604.

5. King, David A., Astronomy and Islamic society: Qibla, gnomonics and timekeeping. In Encyclopedia of the History of Arabic Science (ed. Roshid), 1996, vol. 1, pp. 128-184, 166-167.

6. Karim, A. S. M., A Guide to PRAYER in Islam, The Co-operative Office for Call and Foreigners' Guidance at Sultanah, Riyadh, 1997, pp. 16-17; http://www.islamicbook.ws/english/english-020.pdf

7. http://praytime.org/calculation

8. http://astronomyaardra.org/Astronomy\%20Resources/sun-ra-dec.f.

ACKNOWLEDGEMENTS. We thank the Archeological Survey of India, New Delhi for permission to visit the site. We also thank the staff and attendants at the Red Fort, Agra, for assistance.

Received 2 June 2019; revised accepted 4 January 2021

\section{Traditional knowledge of medicinal plants among the Thangal-Naga ethnic group of Manipur, India}

\section{Babina Pampuinath and Maibam Dhanaraj Meitei*}

Department of Forestry and Environmental Science, Manipur University, Canchipur 795 003, India

With a population of 4475 individuals, the ThangalNaga of Manipur is one of the vulnerable schedule tribe groups in India. During the study, oral traditional knowledge for the treatment of ailments using wild medicinal plants by the ethnic group was documented. Forty-one ethnomedicinal plants from 40 genera and 28 families were reported during the semistructured interviews of 70 locals. In total, 29 different ailments were treated using medicinal plants. Further, phytochemical analysis of 11 common medicinal plants revealed the presence of alkaloids, flavonoids, saponins, tannins, phenols, steroids, anthraquinones, coumarins, glycosides and terpenoids.

Keywords: Ethnomedicinal plants, ethnic groups, photochemical analysis, Thangal-Naga, traditional knowledge.

THANGAL-Naga, also known as Koirao, is one of the endangered, small, tribal ethnic groups in India with a population of 4475 individuals, and represents $0.38 \%$ of Manipur's tribal population ${ }^{1}$. Today, there are only 11 villages in Senapati district of Manipur, viz. Angkailongdi,

*For correspondence. (e-mail: maibam.meitei@yahoo.in) 
Table 1. Plants used in traditional medicine among the Thangal-Naga ethnic group

\begin{tabular}{|c|c|c|c|c|c|c|c|}
\hline $\begin{array}{l}\text { Scientific name, family and } \\
\text { voucher number }\end{array}$ & $\begin{array}{c}\text { Vernacular } \\
\text { name (Thangal) }\end{array}$ & Habit & $\begin{array}{l}\text { Parts } \\
\text { used }\end{array}$ & $\begin{array}{l}\text { Ailment treated } \\
\text { and other uses }\end{array}$ & $\begin{array}{l}\text { Preparation/ } \\
\text { formulation }\end{array}$ & $\begin{array}{c}\text { Routes of } \\
\text { administration }\end{array}$ & Edible use \\
\hline \multicolumn{8}{|l|}{ Acanthaceae } \\
\hline $\begin{array}{l}\text { Phlogacanthus thyrsiformis Nees } \\
\text { BP-2019/22 }\end{array}$ & Tamphanggan & Shrub & Lf & Cold & Boiled Juice & $\begin{array}{l}\text { Oral/ } \\
\text { inhalation/bath }\end{array}$ & $\begin{array}{l}\text { Fw as kanghou; } \\
\text { Lf as chutney }\end{array}$ \\
\hline \multicolumn{8}{|l|}{ Anacardiaceae } \\
\hline $\begin{array}{l}\text { Rhus semialata Murray } \\
\text { BP-2019/07 }\end{array}$ & Khama & Tree & $\mathrm{Fr}$ & Gastric problem & Decoction & Oral & Fr as raw \\
\hline \multicolumn{8}{|l|}{ Apiaceae } \\
\hline $\begin{array}{l}\text { Centella asiatica (L.) Urb. } \\
\text { BP-2019/30 }\end{array}$ & Jopikonggan & Herb & $\mathrm{Wp}$ & $\begin{array}{l}\text { Stomach problems, } \\
\text { blood purifier, } \\
\text { enhanced eyesight }\end{array}$ & Decoction & Oral & $\begin{array}{l}\text { Wp as kangsu } \\
\text { and chamfut }\end{array}$ \\
\hline $\begin{array}{l}\text { Eryngium foetidum L. } \\
\text { BP-2019/14 }\end{array}$ & Majangmikikhom & Herb & Lf & $\begin{array}{l}\text { Epilepsy, paralysis } \\
\text { and high } \\
\text { blood pressure }\end{array}$ & $\begin{array}{l}\text { Paste/decoction/ } \\
\text { fresh }\end{array}$ & $\begin{array}{l}\text { Topical/ } \\
\text { oral }\end{array}$ & Lf as spice \\
\hline \multicolumn{8}{|l|}{ Apocyanaceae } \\
\hline $\begin{array}{l}\text { Rauvolfia serpentina (L.) Benth. } \\
\quad \text { ex Kurz } \\
\text { BP-2019/12 }\end{array}$ & Parisaikoi & Herb & St & Skin infection & Paste & $\begin{array}{l}\text { Topical/ } \\
\text { massage }\end{array}$ & - \\
\hline \multicolumn{8}{|l|}{ Asteraceae } \\
\hline $\begin{array}{l}\text { Eupatorium adenophorum Spreng. } \\
\text { BP-2019/37 }\end{array}$ & Japan phana & Herb & Ts, Lf & Cuts and wounds & Paste & Topical & - \\
\hline $\begin{array}{l}\text { Ageratum conyzoides (L.) L. } \\
\text { BP-2019/08 }\end{array}$ & Majangmi phana & Herb & $\mathrm{Lf}$ & Cuts and wounds & Paste & $\begin{array}{l}\text { Topical/ } \\
\text { massage }\end{array}$ & - \\
\hline \multicolumn{8}{|c|}{$\begin{array}{l}\text { Pamp. } \\
\text { BP-2019/01 }\end{array}$} \\
\hline $\begin{array}{l}\text { Gynura cusimbua (D.Don) Moore. } \\
\text { BP-2019/35 }\end{array}$ & Leishak phana & Herb & $\mathrm{Lf}$ & $\begin{array}{l}\text { Gastric problem } \\
\text { and cleansing of } \\
\text { stomach }\end{array}$ & Decoction & Oral & - \\
\hline $\begin{array}{l}\text { Spilanthes acmella (L.) L. } \\
\text { BP-2019/06 }\end{array}$ & Shagitla & Herb & Fw & $\begin{array}{l}\text { Toothache and } \\
\text { gastric problems }\end{array}$ & Fresh & Oral & - \\
\hline \multicolumn{8}{|l|}{ Bignoniaceae } \\
\hline $\begin{array}{l}\text { Oroxylum indicum (L.) Kurz. } \\
\text { BP-2019/41 }\end{array}$ & Chakkoi & Tree & $\mathrm{Br}, \mathrm{Fr}$ & Piles and cancer & Juice & Oral & Fr as chutney \\
\hline \multicolumn{8}{|l|}{ Caricaceae } \\
\hline $\begin{array}{l}\text { Carica papaya L. } \\
\text { BP-2019/26 }\end{array}$ & Koigithei & Tree & $\mathrm{Lf}$ & $\begin{array}{l}\text { Headache, gastric } \\
\text { and stomach } \\
\text { problems }\end{array}$ & Decoction & Oral & Fr as fresh \\
\hline \multicolumn{8}{|l|}{ Cucurbitaceae } \\
\hline $\begin{array}{l}\text { Momordica charantia } \mathrm{L} \text {. } \\
\quad \text { BP-2019/17 }\end{array}$ & Khalaganthei & Climber & $\mathrm{Lf}$ & Flu and cold & Decoction & Oral & $\begin{array}{l}\text { Fr as chutney } \\
\text { or boiled; Lf as } \\
\text { fresh }\end{array}$ \\
\hline $\begin{array}{l}\text { Echinocystis lobata }(\text { Michx) } \\
\text { Torr. \& A. Gray } \\
\quad \text { BP-2019/18 }\end{array}$ & Ram githei phana & Climber & $\mathrm{Wp}$ & Jaundice & Decoction & Oral & - \\
\hline \multicolumn{8}{|l|}{ Cyperaceae } \\
\hline $\begin{array}{l}\text { Fuirena umbellata Rottb. } \\
\text { BP-2019/33 }\end{array}$ & Ngi & Herb & $\mathrm{Rt}$ & $\begin{array}{l}\text { Fever, swelling of } \\
\text { arms, legs and } \\
\text { stomach problem }\end{array}$ & Decoction & Oral & - \\
\hline \multicolumn{8}{|l|}{ Lamiaceae } \\
\hline $\begin{array}{l}\text { Mentha spicata L. } \\
\text { BP-2019/23 }\end{array}$ & Nungsit pari & Herb & $\mathrm{Lf}, \mathrm{Ts}$ & $\begin{array}{l}\text { Stomach } \\
\text { problems }\end{array}$ & Decoction & Oral & $\begin{array}{l}\text { Ts as flavour- } \\
\text { ing agent }\end{array}$ \\
\hline $\begin{array}{l}\text { Ocimum canum Sims. } \\
\text { BP-2019/09 }\end{array}$ & Hopae & Herb & Lf, Ts & Headache & Decoction & Oral & $\begin{array}{l}\text { Ts as flavour- } \\
\text { ing agent }\end{array}$ \\
\hline \multicolumn{8}{|l|}{ Lauraceae } \\
\hline $\begin{array}{l}\text { Cinnamomum verum J. Presl } \\
\text { BP-2019/02 }\end{array}$ & Sangleikoi & Tree & $\mathrm{Br}$ & $\begin{array}{l}\text { Cough, pain/ } \\
\text { itching }\end{array}$ & Juice/fresh & $\begin{array}{l}\text { Oral/ } \\
\text { topical }\end{array}$ & $\mathrm{Br}$ as spice \\
\hline \multicolumn{8}{|l|}{ Liliaceae } \\
\hline $\begin{array}{l}\text { Allium hookerii Thwaites } \\
\text { BP-2019/32 }\end{array}$ & Sanamnamchenga & Herb & Lf & Deworming & Paste & $\begin{array}{l}\text { Topical/ } \\
\text { massage }\end{array}$ & $\begin{array}{l}\text { Wp as chamfut } \\
\text { and as chutney }\end{array}$ \\
\hline $\begin{array}{l}\text { Allium sativum L. } \\
\quad \text { BP-2019/15 }\end{array}$ & Sanamriba & Herb & Lf & $\begin{array}{l}\text { High blood } \\
\text { pressure, } \\
\text { cough and cold }\end{array}$ & Juice & Oral & $\mathrm{Bl}$ as spice \\
\hline
\end{tabular}


RESEARCH COMMUNICATIONS

Table 1. (Contd)

\begin{tabular}{|c|c|c|c|c|c|c|c|}
\hline $\begin{array}{l}\text { Scientific name, family and } \\
\text { voucher number }\end{array}$ & $\begin{array}{c}\text { Vernacular } \\
\text { name (Thangal) }\end{array}$ & Habit & $\begin{array}{l}\text { Parts } \\
\text { used }\end{array}$ & $\begin{array}{l}\text { Ailment treated } \\
\text { and other uses }\end{array}$ & $\begin{array}{l}\text { Preparation/ } \\
\text { formulation }\end{array}$ & $\begin{array}{c}\text { Routes of } \\
\text { administration }\end{array}$ & Edible use \\
\hline \multicolumn{8}{|l|}{ Lythraceae } \\
\hline $\begin{array}{l}\text { Punica granatum L. } \\
\text { BP-2019/20 }\end{array}$ & Pulangtheikoi & Tree & Rt & Dysentery & Juice & Oral & Fr as fresh \\
\hline \multicolumn{8}{|l|}{ Meliaceae } \\
\hline $\begin{array}{l}\text { Azadirachta indica A. Juss. } \\
\text { BP-2019/04 }\end{array}$ & Neemkoi & Tree & Lf & Fever and cough & Decoction & Oral & - \\
\hline \multicolumn{8}{|l|}{ Mimosaceae } \\
\hline $\begin{array}{l}\text { Mimosa pudica } \mathrm{L} \text {. } \\
\text { BP-2019/40 }\end{array}$ & Kajakpi phana & Herb & Wp & $\begin{array}{l}\text { Piles and stone } \\
\text { problems }\end{array}$ & Decoction & Oral & - \\
\hline $\begin{array}{l}\text { Parkia javanica Merr. } \\
\text { BP-2019/34 }\end{array}$ & Kajongtakkoi & Tree & $\mathrm{Fr}$ & $\begin{array}{l}\text { Diarrhoea and } \\
\text { dysentery }\end{array}$ & Boiled juice & Oral & $\begin{array}{l}\text { Fr as singju } \\
\text { and iromba; } \\
\text { Fw as singju }\end{array}$ \\
\hline \multicolumn{8}{|l|}{ Musaceae } \\
\hline $\begin{array}{l}\text { Musa paradisiaca } \mathrm{L} \text {. } \\
\text { BP-2019/39 }\end{array}$ & Poitheikoi & Tree & $\mathrm{Fr}$ & Diarrhoea & Fresh & Oral & $\begin{array}{l}\text { Fw as fried item; } \\
\text { St as iromba; } \\
\text { Fr as fresh }\end{array}$ \\
\hline \multicolumn{8}{|l|}{ Myristicaceae } \\
\hline $\begin{array}{l}\text { Myristica linifolia Roxb. } \\
\text { BP-2019/25 }\end{array}$ & Ripkoi & Tree & Lf & Cuts and wounds & Paste & $\begin{array}{l}\text { Topical/ } \\
\text { massage }\end{array}$ & - \\
\hline \multicolumn{8}{|l|}{ Oxalidaceae } \\
\hline $\begin{array}{l}\text { Oxalis corniculata } \mathrm{L} \text {. } \\
\text { BP-2019/29 }\end{array}$ & Pit & Herb & Lf & $\begin{array}{l}\text { Indigestion and } \\
\text { gastric problem }\end{array}$ & Decoction & Oral & Lf as kangsoi \\
\hline \multicolumn{8}{|l|}{ Plantaginaceae } \\
\hline $\begin{array}{l}\text { Plantago major L. } \\
\text { BP-2019/38 }\end{array}$ & Kapatnougan & Herb & Lf & $\begin{array}{l}\text { Blood clot and } \\
\text { boils }\end{array}$ & Paste & $\begin{array}{l}\text { Topical/ } \\
\text { massage }\end{array}$ & Lf in iromba \\
\hline \multicolumn{8}{|l|}{ Poaceae } \\
\hline $\begin{array}{l}\text { Cynodon dactylon } \mathrm{L} \text {. } \\
\text { BP-2019/05 }\end{array}$ & Phlim & Herb & $\mathrm{Wp}$ & $\begin{array}{l}\text { Fever and } \\
\text { typhoid }\end{array}$ & Juice & Oral & - \\
\hline \multicolumn{8}{|l|}{ Rosaceae } \\
\hline $\begin{array}{l}\text { Rubus ellipticus Sm. } \\
\text { BP-2019/03 }\end{array}$ & Machikthei & Shrub & Rt & Diarrhoea & Juice & Oral & Fr as fresh \\
\hline \multicolumn{8}{|l|}{ Rubiaceae } \\
\hline $\begin{array}{l}\text { Meyna laxiflora Robyns } \\
\text { BP-2019/36 }\end{array}$ & Habitheikoi & Tree & Lf & $\begin{array}{l}\text { Swelling of the } \\
\text { body }\end{array}$ & Decoction & Oral & $\begin{array}{l}\text { Lf as fresh in } \\
\text { singju; Fr as } \\
\text { dried }\end{array}$ \\
\hline $\begin{array}{l}\text { Paederia foetida } \mathrm{L} . \\
\text { BP-2019/19 }\end{array}$ & Beireng & Climber & Lf & Bone fracture & Paste & $\begin{array}{l}\text { Massage/ } \\
\text { topical }\end{array}$ & - \\
\hline \multicolumn{8}{|l|}{ Rutaceae } \\
\hline $\begin{array}{l}\text { Citrus limon (Linn.) Burm. f. } \\
\text { BP-2019/10 }\end{array}$ & Champra & Shrub & $\mathrm{Fr}$ & Fever & Fresh & Massage & Fr as fresh \\
\hline $\begin{array}{l}\text { Zanthoxylum acanthopodium DC } \\
\text { BP-2019/27 }\end{array}$ & Ngangtheikoi & Tree & $\mathrm{Fr}$ & Toothache & Fresh & Oral & $\begin{array}{l}\text { Fr in chutney; } \\
\text { Lf as spice }\end{array}$ \\
\hline \multicolumn{8}{|l|}{ Sapindaceae } \\
\hline $\begin{array}{l}\text { Sapindus mukorossi Gaertn. } \\
\text { BP-2019/13 }\end{array}$ & Talumthei & Tree & Fr & $\begin{array}{l}\text { Fever and } \\
\text { deworming }\end{array}$ & Juice & $\begin{array}{l}\text { Topical/ } \\
\text { massage }\end{array}$ & - \\
\hline \multicolumn{8}{|l|}{ Saururaceae } \\
\hline $\begin{array}{l}\text { Houttuynia cordata Thunb. } \\
\text { BP-2019/31 }\end{array}$ & Dana & Herb & $\begin{array}{l}\mathrm{Wp} \\
\mathrm{Rz}\end{array}$ & $\begin{array}{l}\text { Muscle cramp, } \\
\text { eye and skin } \\
\text { irritation, measles, } \\
\text { stomach ulcers }\end{array}$ & $\begin{array}{l}\text { Decoction/ } \\
\text { juice }\end{array}$ & Oral & $\begin{array}{l}\text { Lf as fresh } \\
\text { spice }\end{array}$ \\
\hline \multicolumn{8}{|l|}{ Solanaceae } \\
\hline $\begin{array}{l}\text { Solanum torvum Sw. } \\
\text { BP-2019/11 }\end{array}$ & Khukthei & Shrub & $\mathrm{Fr}$ & $\begin{array}{l}\text { Fever and } \\
\text { typhoid }\end{array}$ & Juice & Oral & Fr as chutney \\
\hline \multicolumn{8}{|l|}{ Verbenaceae } \\
\hline $\begin{array}{l}\text { Clerodendrum colebrookianum } \\
\text { Walp. BP-2019/24 }\end{array}$ & Pokdomna & Tree & Lf & $\begin{array}{l}\text { Blood } \\
\text { pressure }\end{array}$ & Decoction & Oral & Lf as curry \\
\hline \multicolumn{8}{|l|}{ Zingiberaceae } \\
\hline $\begin{array}{l}\text { Alpinia galangal (L.) Willd. } \\
\text { BP-2019/21 }\end{array}$ & Jaikhaba & Herb & $\mathrm{Rz}$ & $\begin{array}{l}\text { Cough and } \\
\text { diarrhoea }\end{array}$ & $\begin{array}{l}\text { Paste/ } \\
\text { decoction }\end{array}$ & $\begin{array}{l}\text { Topical/ } \\
\text { oral }\end{array}$ & Rz as spice \\
\hline $\begin{array}{l}\text { Curcuma longa } \mathrm{L} \text {. } \\
\text { BP-2019/28 }\end{array}$ & Marenggai & Herb & $\mathrm{Rz}$ & $\begin{array}{l}\text { Swelling of } \\
\text { the body }\end{array}$ & Paste & $\begin{array}{l}\text { Topical/ } \\
\text { massage }\end{array}$ & Rz as spice \\
\hline $\begin{array}{l}\text { Zingiber officinale Roscoe } \\
\text { BP-2019/16 }\end{array}$ & Saraikaga & Herb & $\mathrm{Rz}$ & Sore throat & Fresh & Oral & Rz as spice \\
\hline
\end{tabular}

Br, Bark; Fr, Fruits; Fw, Flowers; Lf, Leaves; St, Stem; Ts, Tender shoots; Rt, Roots; Rz, Rhizomes; Wp, Whole plants. 
Katomei Makeng, Makeng Cheijinba, Ngaihang, Mapao Thangal, Mayangkhang, Ningthoupham, Thangal Surung, Tumnoupokpi, Yaikongpao and Takaimei where Thangal habitations are found ${ }^{2}$. Traditionally, Thangals are agriculturists and horticulturists with experience in jhum cultivation. The womenfolk are mostly skilled weavers making indigenous hand-woven clothes. They have lived with the sustainable use of forest and plant resources, such as wild edible plants, timber, fruits, medicinal herbs, flowers, orchids, etc. and depend on them directly or indirectly for their livelihood ${ }^{3}$. Like the major ethnic groups of Manipur, Thangals have acquired the traditional knowledge of using plants for healing different ailments since generations. They have maintained their own ethnic identity, customs, beliefs, faith and tradition. However, the indigenous traditional ways are disappearing from the society under the influence of modernization and industrialization. Today, lack of proper documentation has resulted in the disappearance of important ethnomedicinal knowledge from different indigenous ethnic groups, where the age-old traditions are being replaced by modern allelopathic practices. Therefore, there is an urgent need to update the traditional knowledge of these ethnic groups.

In this study, the ethnomedicinal knowledge was collected from 11 Thangal-inhabiting villages of Senapati district during 2018-19. Information on ethnomedicinal plants such as local name, ailments treated, plant parts used, preparation methods and administration routes was
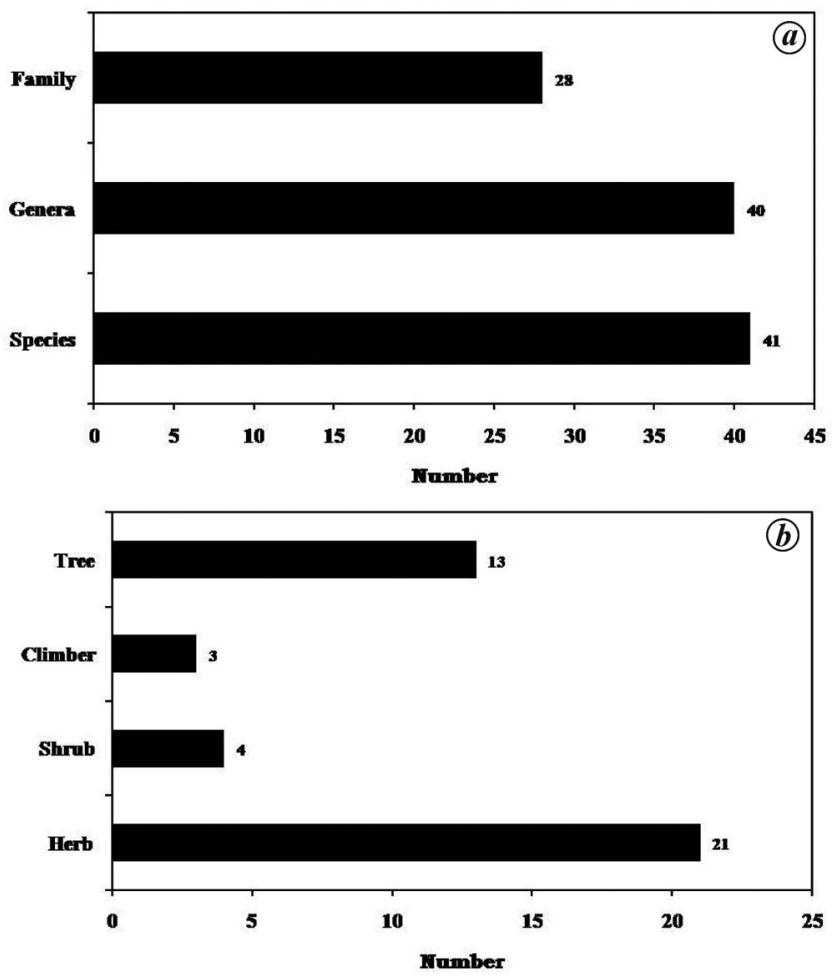

Figure 1. Distribution of (a) plant species, genera and families and (b) growth forms and habits. collected using semi-structured interviews. Voucher specimens collected were identified with the help of experts and the available literatures ${ }^{4-6}$. The scientific name and family were cross-checked using the PlantList (www.theplantlist.org) of the Royal Botanic Garden, Kew, UK. Voucher specimens (BP-2019/01 to BP2019/41) were then deposited in the Department of Forestry and Environmental Science, Manipur University. Eleven common medicinal plants (Cynodon dactylon and Centella asiatica whole plant, Oroxylum indicum and Cinnamomum verum bark, Eupatorium adenophorum and Ageratum conyzoides leaves, Musa paradisiaca and Solanum torvum fruits, Alpinia galangal and Curcuma longa rhizomes and Spilanthes acmella flowers) were collected and qualitative analysis of the phytochemicals was performed (water extract) ${ }^{7,8}$.

Among the 70 locals included in the ethnobotanical survey, $80 \%$ were men and $20 \%$ were women. A great disparity was noticed in the distribution of the traditional
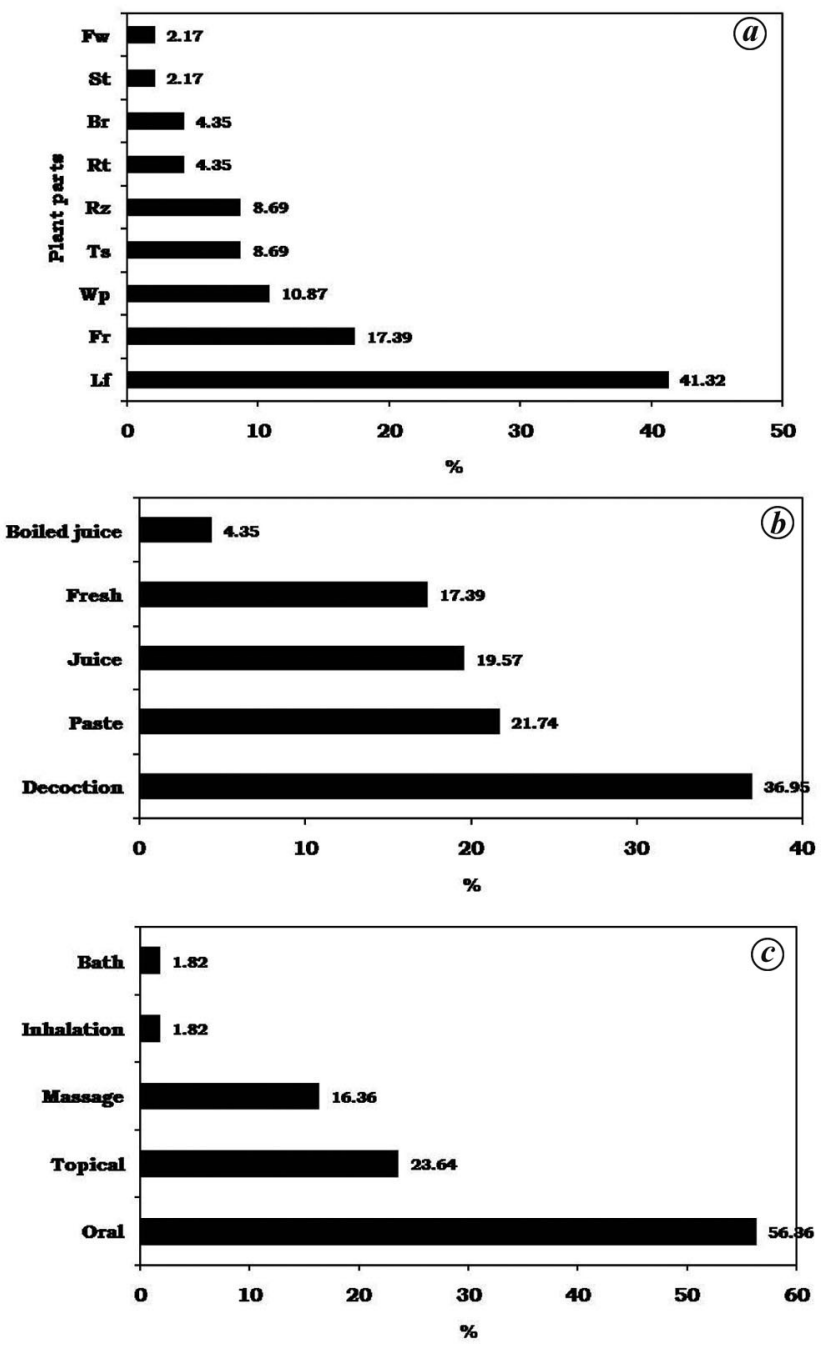

Figure 2. Percentage distribution of (a) plant parts used, (b) mode of preparation and $(c)$ route of administration.

CURRENT SCIENCE, VOL. 120, NO. 5, 10 MARCH 2021 


\section{RESEARCH COMMUNICATIONS}

Table 2. Phytochemical screening of common medicinal plants

\begin{tabular}{|c|c|c|c|c|c|c|c|c|c|c|}
\hline \multirow[b]{2}{*}{ Plant } & \multicolumn{10}{|c|}{ Phytochemicals } \\
\hline & Flavonoids & Tannins & Phenols & Terpenoids & Steroids & Saponins & $\begin{array}{l}\text { Anthra- } \\
\text { quinones }\end{array}$ & Coumarins & Glycosides & Alkaloids \\
\hline Cynodon dactylon & + & - & + & - & - & + & - & + & - & + \\
\hline Centella asiatica & + & + & + & - & + & - & - & - & - & + \\
\hline $\begin{array}{l}\text { Oroxylum } \\
\text { indicum }\end{array}$ & + & - & - & - & - & + & + & - & - & + \\
\hline $\begin{array}{l}\text { Cinnamomum } \\
\text { verum }\end{array}$ & - & - & - & + & - & - & + & - & - & + \\
\hline $\begin{array}{l}\text { Eupatorium } \\
\text { adenophorum }\end{array}$ & - & + & + & - & + & + & + & - & - & + \\
\hline $\begin{array}{l}\text { Ageratum } \\
\text { conyzoides }\end{array}$ & + & + & + & - & + & + & - & + & - & + \\
\hline Musa paradisiaca & - & - & - & - & - & - & - & - & - & - \\
\hline Solanum torvum & - & - & - & - & - & + & - & + & - & + \\
\hline Curcuma longa & + & - & - & + & + & + & + & - & - & + \\
\hline Alpinia galangal & - & - & - & - & - & + & - & + & - & + \\
\hline $\begin{array}{l}\text { Spilanthes } \\
\text { acmella }\end{array}$ & + & - & - & - & + & - & - & + & - & + \\
\hline
\end{tabular}

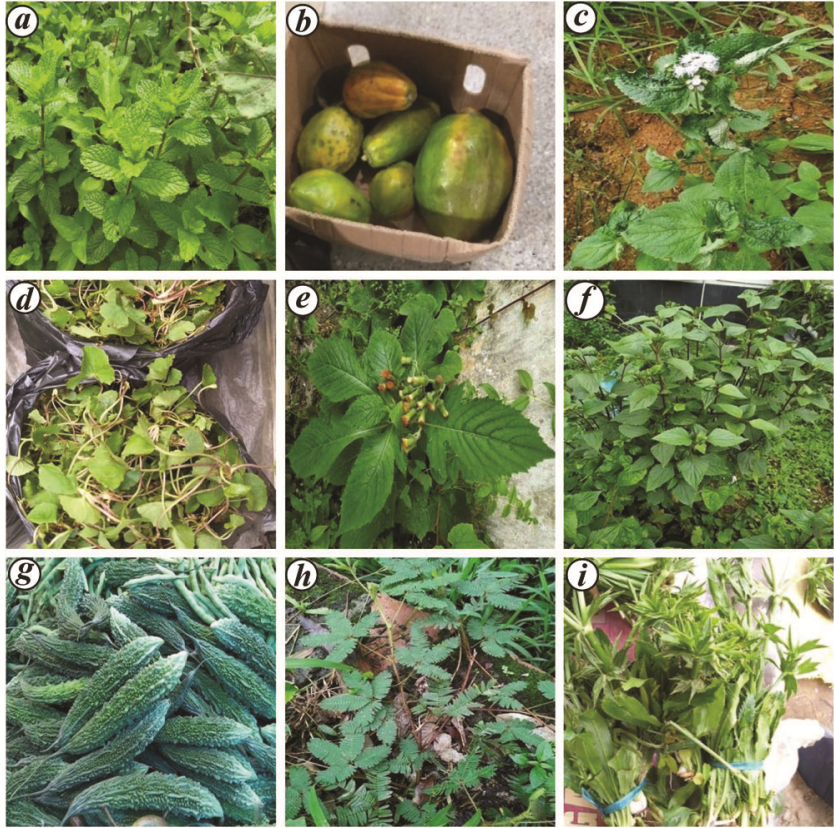

Figure 3. Photographs of common medicinal plants. a, Mentha spicata; $\boldsymbol{b}$, Carica papaya; $\boldsymbol{c}$, Ageratum conyzoides; $\boldsymbol{d}$, Centella asiatica; $\boldsymbol{e}, \mathrm{Gy}$ nura cusimbua; $\boldsymbol{f}$, Eupatorium adenophorum; $\boldsymbol{g}$, Momordica charantia; $\boldsymbol{h}$, Mimosa pudica; $\boldsymbol{i}$, Eryngium foetidum.

knowledge between the sexes, where the tradition is a male-inherited system. Moreover, the healers mostly belonged to the aged population of the community with the younger generation favouring modern methods of treatment. During knowledge transmission, elders usually pass on the information and treatment processes to their near ones orally, thus restricting the number of individuals with the said knowledge. This is a common tradition observed in different indigenous groups ${ }^{9,10}$. In total, 41 species from 40 genera and 28 families were documented (Table 1). A. conyzoides, E. adenophorum, C. asiatica, $C$. dactylon, $O$. canum, $P$. thyrsiformis, $P$. major, $S$. torvum and $Z$. officinale were commonly recommended by the healers. The maximum use reports were found for treating ailments such as gastric and stomach problems, fever, diarrhoea and dermatological problems due to their greater prevalence in the region ${ }^{1}$. The common preferred species belonged to families Asteraceae, Zingiberaceae, Lamiaceae, Rubiaceae, Apiaceae, Liliaceae and Cucurbitaceae. Moreover, herbs were the major ethnomedicinal source, which explains the rich herbaceous species wealth of the region $^{3}$ (Figure 1). The traditional healers generally used nine different plant parts during the preparation of crude drugs (Figure $2 a$ ). The maximum use was reported for leaves (19 species), as the collection was easier and resources were available in large volumes compared to other parts. Moreover, the harvest of the leaves can cause minimum damage compared to other parts from the conservation point of view. Likewise, the parts were prepared under five categories and the crude drugs administered via five routes (Figure $2 b$ and $c$ ). The healers were well aware of the preparation methods and routes for administration, so that maximum efficiency could be achieved for the drug. Further, it was observed that most of the drugs were administered orally as it was the most effective means, which is similar to numerous findings ${ }^{11,12}$. Moreover, 27 species from 26 genera and 21 families were consumed in the local households in traditional cuisines (Table 1 and Figure 3). Phytochemical analysis of the 11 ethnomedicinal plants showed the presence of flavonoids, tannins, phenols, terpenoids, saponins, coumarins, anthocyanin, anthraquinones, glycosides, alkaloids and steroids (Table 2). The analysis supports the selection of a particular species by the healers for traditional medicine. Thus, 
the present study highlights the rich, disappearing, traditional ethnomedicinal knowledge which is scattered in oral form within the Thangal-Naga ethnic group of Manipur. Such knowledge needs proper documentation for use, preservation and protection.

Conflict of interest. Authors declare no conflict of interest.

1. Census of India, Census data. Office of the Registrar General and Census Commissioner, Ministry of Home Affairs, Government of India (GoI), 2011; https://censusindia.gov.in/2011-common/ censusdata2011.html (assessed on 14 June 2020).

2. Maibam, M., Maibam, A. and Akoijam, B., Myths of Thangal origin from an anthropological perspective. Int. J. Hum. Soc. Sci., 2017, 11(8), 2043-2046.

3. Forest Survey of India, State of Forest Report. Ministry of Environment and Forests and Climate Change, GoI, 2011; https://www.fsi.nic.in/forest-report-2011 (assessed on 4 July 2020).

4. Kanjilal, U. N., Kanjilal, P. C., De, R. N., Das, A. and Bor, N. L., Flora of Assam, Government of Assam, Shillong, 1934-1940, vols $1-5$.

5. Deb, D. B., Dicotyledonous plants of Manipur territory. Bull. Bot. Surv. India, 1961, 3(3), 253-350.

6. Brummitt, R. K. and Powell, C. E., Authors of plant names: a list of authors of scientific names of plants, with recommended standard forms of their names, including abbreviations. Royal Botanic Gardens, Kew, UK, 1992.
7. Jaradat, N. A., Hussen, F. M. and Ali, A. A., Preliminary phytochemical screening, quantitative estimation of total flavonoids, total phenols and antioxidant activity of Ephedra alata Decne. J. Mater. Environ. Sci., 2015, 6(6), 1771-1778.

8. Ajuru, M. G., Williams, L. F. and Ajuru, G., Qualitative and quantitative phytochemical screening of some plants used in ethnomedicine in the Niger delta region of Nigeria. Int. J. Food Chem., 2017, 1, 7-14.

9. Meitei, M. D. and Prasad, M. N. V., Phoomdi-a unique plant biosystem of Loktak lake, Manipur, North-East India: traditional and ecological knowledge. Plant Biosyst., 2015, 149(4), 777-787.

10. Sodipo, O. A. and Wannang, N. N., Ethno pharmacological survey of plants used by trado-medical practitioners (TMPs) in the treatment of typhoid fever in Gomari Airport Ward, Jere local government area, Borno State, Nigeria. Am. J. Ethnomed., 2015, 2, 185218.

11. Namsa, N. D., Mandal, M., Tangjang, S. and Mandal, S. C., Ethnobotany of the Monpa ethnic group at Arunachal Pradesh, India. J. Ethnobiol. Ethnomed., 2011, 7, 31.

12. Salam, S. and Jamir, N. S., Common spices plant used as medicine by the Tangkhul tribe of Ukhrul district, Manipur, India. Int. J. Sci. Res. Publ., 2016, 6(7), 2250-3153.

ACKNOWLEDGEMENT. We thank the locals of 11 villages in Senapati district, Manipur for help during the field visit.

Received 1 October 2020; revised accepted 18 January 2021

doi: $10.18520 /$ cs/v120/i5/945-950 